\title{
Use of Force as Self Defence against Non-State Actors and TWAIL Considerations: A Critical Analysis of India's State Practice
}

\author{
Srinivas Burra*
}

International law on the use of force has been prominently a contentious issue in the last two decades. This has been mainly after the September 11 incident. International law dealing with the use of force, principally on self defence, is sought to be applied in contexts which arguably are contentious. While Article 2(4) of the United Nations Charter prohibits the use of force in international law, Article 51 provides for the possibility of the use of force as self defence. In accordance with the text of Article 51, it is generally understood that the use of force as self defence takes place by a state against another state. However, in the recent instances of uses of force, it is asserted that this right of self defence can be invoked by a state while using force against nonstate actors (NSAs) operating from another state. States which are in favour of the invocation of Article $5^{1}$ in such situations of force argue that if the state from which the non-state actor is operating is unwilling or unable to deal with the non-state actors, the state which is the target of the non-state actor has the right of self defence. This argument is primarily relied upon by a few states while justifying their use of force in the recent past. These states mainly include the United States of America, the United Kingdom, Turkey and France, who claimed individual self defence against the Islamic State (IS ). ${ }^{1}$

* Assistant Professor, Faculty of Legal Studies, South Asian University, New Delhi, India. A draft of this article was presented at the 2019 DILA-KOREA International Conference on 'Asian State Practice in International Law from the Lens of TwAIL', November 7-9, 2019, Seoul, Korea. The author thanks the participants of the conference for their valuable comments on the draft. He also thanks DILA-KOREA for facilitating his participation in the conference.

1 Permanent Rep. of the United States to the U.N., Letter dated September 23, 2014 from the Permanent Rep. of the United States to the United Nations addressed to the U.N. Secretary-General, U.N. Doc. S/2014/695 (Sept. 14, 2014); Permanent Rep. of the United Kingdom of Great Britain and Northern Ireland to the U.N., Identical letters dated November 25, 2014 from the Permanent Rep. of the United Kingdom of Great Britain and Northern Ireland addressed to the United Nations addressed to the Secretary-General and the President of the Security Council, U.N. Doc. S/2014/851 (Nov. 26, 2014); Permanent Rep. of the United Kingdom of Great Britain and Northern Ireland to the U.N., Letter dated September 7, 2015 from the Permanent Rep. of the United Kingdom of Great Britain and Northern Ireland to the United

(C) SRINIVAS BURRA, 2020 | DOI:10.1163/9789004437784_007

This is an open access chapter distributed under the terms of the CC BY-NC-ND 4.glicenses Burra - 9789004437784 
India has been involved in situations of use of force on several occasions. Some of these situations clearly amounted to armed conflicts. However, there were instances in which India resorted to the use of force against another state, primarily claiming to target non-state actors. In such situations, it was not clearly argued that the use of force was in self defence against non-state actors. At the same time, it was also not clearly spelt out as to what it would amount to. This article analyses India's state practice in relation to the use of force that it resorted to targeting the non-state actors on the territory of another state. It intends to critically evaluate India's positions to draw conclusions on the issue of the right of self defence against NSAs operating from the other state. It explores India's position at the multilateral fora on the issue. It also evaluates TWAIL methodological insights in relation to the right of self defence against NSAs. Part one of this article provides the introduction. Part two deals with the legal framework on the use of force. This is followed by part three which provides India's state practice in relation to its use of force against the nonstate actors on the territory of another state. Part four presents Third World Approaches to International Law (TWAIL) reflections on the issue. Part five provides the conclusion.

The use of force in interstate relations is arguably comprehensively dealt with by the United Nations Charter. While prohibiting the use of force by states under Article 2(4), the UN Charter permits and regulates it in certain circumstances as exceptions to the general prohibition. Therefore, the general prohibition is qualified with two exceptions. One exception is in the form of permissibility of the use of force as self defence under article $5^{1}$ of the UN Charter. The other exception is the use of force with the authorization of the United Nations Security Council (UNSC) which is governed by Article 42 of the Charter. Self defence under Article $5^{1}$ primarily visualizes the immediate response of a state which is the victim of an armed attack. This immediate response may take the form of individual or collective self defence. Article 42

Nations addressed to the President of the Security Council, U.N. Doc. S/2015/688 (Sept. 8, 2015); Chargé d'affaires a.i. of the Permanent Mission of Turkey to the U.N., Letter dated July 24, 2015 from the Chargé d'affaires a.i. of the Permanent Mission of Turkey to the United Nations addressed to the President of the Security Council, U.N. Doc. S/2015/563 (July 24, 2015); Permanent Rep. of France to the U.N., Identical letters dated September 8, 2015 from the Permanent Rep. of France to the United Nations addressed to the Secretary-General and the President of the Security Council, U.N. Doc. S/2015/745 (Sept. 9, 2015). 
of the UN Charter envisages institutional collective security response to the use of force against a state in violation of Article 2(4).

\subsection{Legal Framework on the Right of Self Defence}

In the last two decades, mainly from the September 11, 2001 incident, there has been an increase in scholarly discussions as well as contending views of states on the scope of Article $5^{1}$ of the UN Charter. These views also relate the discussion to the resolutions adopted by the UN Security Council after the September 11 incident. These resolutions mainly are: 1368 and 1373 adopted in September 2001 which make references to self defence. ${ }^{2}$

This discussion is different from others that took place on the right of self defence that revolved around anticipatory self defence and issues relating to necessity and proportionality. The present discussion is related to the scope of Article 51, focusing on when the right of self defence of a state gets activated. In other words, whether the right of self defence can be exercised by a state even if the armed attack comes from NSAs. This discussion continues to attain significance in the context of fights against terrorism and other non-state actors. This situation is experienced in the contexts of Syria, Libya, Yemen and other similar contexts. The possibility or impossibility of exercising the right of self defence by the victim state, the state which is the target of an armed attack, is evaluated from various standpoints. These standpoints can be categorized as textual analysis, customary international law perspective and analysis based on state practice. The justification for the use of force as self defence against NSAs is predominantly justified, not from political or policy considerations, but in formalist legal analyses. The first proposition of this justification comes from the interpretation of the existing law. This justification primarily relies on the interpretation of Article 51 of the UN Charter. Proponents on the view

2 S.C. Res. 1368, (Sept. 12, 2001). In its preamble, it includes the following paragraphs:

"Determined to combat by all means threats to international peace and security caused by terrorist acts,

Recognizing the inherent right of individual or collective self-defence in accordance with the Charter".

Similarly, in S.C. Res. 1373, (Sept. 28, 2001), the Security Council includes:

"Reaffirming its resolutions 1269 (1999) of 19 October 1999 and 1368 (2001) of 12 September 20o1, ...

Reaffirming further that such acts, like any act of international terrorism, constitute a threat to international peace and security,

Reaffirming the inherent right of individual or collective self-defence as recognized by the Charter of the United Nations as reiterated in resolution 1368 (2001),

Reaffirming the need to combat by all means, in accordance with the Charter of the United Nations, threats to international peace and security caused by terrorist acts". 
that the right of self defence exists against non-state actors operating from another state even if the second state does not have any role to play in the activities of the NSA, rely on the text of Article $5^{1}$ as one of their arguments. They argue that the textual reading of Article 51 does not support the view that the armed attack should come from states only. They underline that the text of Article 51 does not refer to the attack from the state but merely refers to armed attacks. The relevant part of Article 51 states, "Nothing in the present Charter shall impair the inherent right of individual or collective self-defence if an armed attack occurs against a Member of the United Nations, until the Security Council has taken measures necessary to maintain international peace and security". ${ }^{3}$

The text only says "if an armed attack occurs" without specifying that the armed attack should come from a state. Therefore, it is argued that the armed attack can also come from NSAs and that what matters is the armed attack and not the attacker. ${ }^{4}$ Hence, it is argued that "the focus of Art. ${ }^{1}$ refers to the definition of the term 'armed attack'. If states suffer from an armed attack in the sense of Art. 51 they have the right to react by using force irrespective of who is the author of the attack, a state or a non-State actor". ${ }^{5}$ While the merit of this argument is drawn from the plain text of the provision, it apparently fails to take into consideration the nature of Article $5^{1}$ in the Charter framework. Article 51 provides an exception to the general prohibition on the use of force as provided in Article 2(4) of the Charter. The text of this provision clearly provides for the prohibition of use of force in interstate relations. This provision reads, "All Members shall refrain in their international relations from the threat or use of force against the territorial integrity or political independence of any state, or in any other manner inconsistent with the Purposes of the United Nations". ${ }^{6}$

It states that all members of the UN refrain from the threat or use of force. Article 3, which talks about states that are original members, and Article 4, which talks about the new members, refer only to states. Therefore, the prohibition of the use of force in the Charter framework is confined only to interstate use of force. When the prohibition of the use of force is confined only to interstate relations, an exception in the form of Article $5^{1}$ cannot be read as covering the use of force involving NSAS. There is a logical link between the

3 U.N. Charter art. 51.

4 Karin Oellers-Frahm, Article 51 - What Matters is the Armed Attack, not the Attacker, 77 ZaöRV 49 (2017).

5 Id.

6 U.N. Charter art. $2, \boldsymbol{~} 4$. 
legal prohibition and an exception to such prohibition because the confines of the latter are determined by the scope of the former. An exception always needs to be read and understood only in relation to the general framework because the latter decides the contours of the former. Thus, in the present case as Article 2(4) prohibits interstate use of force, the exception in the form of Article 51 needs to be understood only within those confines. Understanding Article 51's reference only to armed attack as inclusive of armed attack from NSAs would at best remain as speculative, devoid of coherence enshrined in the UN Charter. On the other hand, reading the scope of Article 51 in relation to Article 2(4) and therefore understanding it as governing only the interstate use of force is very much within the framework of the UN Charter. For a longer period, there was no doubt that the reference to armed attack was understood as armed attack between states only. ${ }^{7}$ Despite this logical coherence between Article 2(4) and 51, there are arguments that the drafters introduced a disconnect between the two provisions. This view underlines that if the drafters wanted a logical continuity between Article 2(4) and 51, they would have constructed Article $5^{1}$ similar to Article 2(4) which prohibits the threat or use of force against the territorial integrity or political independence of any state. ${ }^{8}$ Therefore, they are of the view that though Article 51 provides an exception to Article 2(4), its nature is different as it encompasses non-state actors also. This argument, however, does not overcome the logical incoherence it leads to in the larger Charter framework.

\subsection{Right of Self Defence and Customary International Law}

The second important proposition that is relied upon to justify the right of self defence against NSAs is based on customary international law. It is argued that there exists the right of self defence as part of customary international law. This argument attempts to establish customary international law on the right of self defence of a state against non-state actors operating from a third state based on the text of Article 51 itself. It is argued that Article $5^{1}$ does not create the right of self defence and only recognises an existing right. The

7 However, there is a contrary opinion that "[w]hether States can use force in response to armed attacks by non-State actors operating from abroad is not a new issue that suddenly became relevant after $9 / 11$. Views have no doubt changed over the past fifteen years, as more States have invoked, or endorsed the invocation of, self-defence against attacks by nonState actors. However, change is more gradual than is usually admitted". Christian J. Tams, Embracing the Uncertainty of Old: Armed Attacks by Non-State Actors Prior to 9/11, 77 ZaöRV 61, $61(2017)$.

8 Sean D. Murphy, Self-Defense and the Israeli Wall Advisory Opinion: An Ipse Dixit from the ICJ?, 99 The AMERican Journal of International LAW 62, 64 (2005). 
text of Article $5^{1}$ states that "Nothing in the present Charter shall impair the inherent right of individual or collective self-defence". ${ }^{9}$ It is, therefore, argued that the reference to "inherent" in this provision is underlined as basis to argue that customary international law on self defence exists. Here, "inherent" is seen as referring to the existence of the right of self defence outside the UN Charter framework, and the Charter only recognises that right. Outside the UN Charter, the right of self defence exists in the form of customary international law. This view further argues that the right of self defence under customary international law is more expansive than the right of self defence under Article 51. This expansive right also includes the use of force against non-state actors.

This argument is traced to the origins of customary international law on self defence which relies on the Caroline incident. ${ }^{10}$ The Caroline incident took place in the nineteenth century. It mainly involved the United Kingdom and the United States. It was related to the territory of Canada, which was still under British control. Those who were fighting against the British rule were involved in violent resistance. This violent resistance sometimes took place from the territory of the United States. In 1837, the Caroline, a vessel used in one such attack, was destroyed by the United Kingdom while it was in US waters. The content of the exchanged letters between Daniel Webster, on behalf of the United States, and Lord Ashburton, on behalf of the United Kingdom, arguably laid the foundation for establishing the law on self defence. In his letter to Webster, offering an explanation for the United Kingdom's use of force against the Caroline while it was on US waters, Ashburton declares that there are "possible cases in the relations of nations, as of individuals, where necessity ... may be pleaded".11 In response, Webster, while admitting the existence of self defence, notes that it is "confined to cases in which the 'necessity of that self defence is instant, overwhelming, and leaving no choice of means, and no moment for deliberation"'. ${ }^{12}$ Along with those conditions that are necessary before self defence became legitimate, the action taken in pursuance of it

$9 \quad$ U.N. Charter art. 51.

10 For details of the Caroline incident, see Michael Wood, The Caroline Incident-1837, in THE Use of Force in International Law: A Case-Based Approach 5 (Tom Ruys et al. eds., 2018); see also Abraham Sofaer, On the Necessity of Pre-Emption, 14 EURopeAN JOURNAL OF INTERNATIONAL LAW 209, 214-20 (2003).

11 John Basset Moore, 2 A Digest of International LaW as Embodied in Diplomatic Discussions, Treaties and Other International Agreements $411(1906)$.

$12 I d$. at 412 . 
must not be unreasonable or excessive, "since the act, justified by the necessity of self-defence, must be limited by that necessity, and kept clearly within it".13

The Caroline incident is not only taken as the beginning of the right of self defence under customary international law, but it is also being relied upon for the purpose of justifying the use of force as self defence against NSAs. It is argued that the use of force by the United Kingdom was against the acts of NSAs, though it took place in United States waters. Thus, it is argued that the use of force as self defence against NSAs was not opposed then and continues to be part of contemporary customary international law understanding of the right of self defence. ${ }^{14}$ This expansive understanding of customary international law on self defence has its conceptual and historical gaps. One conceptual gap arises from the fact that the comprehensive prohibition of the use of force took place only in 1945 as part of the UN Charter. Prior to that, states had fairly established freedom to go to war, with certain restrictions at some historical junctures, for example, in the form of just war. When we relate this historical position with the right of self defence, it becomes difficult to establish the scope of customary international law on the right of self defence. This is so, because it is difficult to imagine the right of self defence when there was no clear legal prohibition on the use of force. When there was no clear prohibition of use of force, there was no legal necessity to prove that the right of self defence existed for the purpose of legally justifying the use of force.

Thus, it is underlined that that the exchange between Ashburton and Webster in the Caroline incident which constituted customary international law is filled with inconsistencies. This fairly coherent assertion views that "For the exchange in the Caroline incident to be formative (or even reflective of a rule of customary international law), the resort to force had to be prohibited under international law at the time of the exchange. Self-defence, as an exception under international law, can only make sense where international law prohibits the resort to force". ${ }^{15}$ Another important historical as well as conceptual issue is that a single incident involving only two states led to the formation of a rule of customary international law. The critics rightly argue that it "is not clear how the Caroline incident meets the requirements of a widespread or general practice. Those advancing it as constitutive of customary international law make no attempt to show acquiescence on the part of other States. The

13 Malcom N. Shaw, International LaW 1131 (6th ed. 2008).

14 Elizabeth Wilmshurst, The Chatham House Principles of International Law of the Use of Force in Self-Defense, 55 International and Comparative LaW Quarterly 963 (2006).

15 Dire Tladi, The Use of Force in Self-Defence Against Non-State Actors, Decline of Collective Security and the Rise of Unilateralism: Whither International Law?, in 1 SELf-Defence Against Non-State Actors 14, 53 (Ann Peters \& Christian Marxsen eds., 2019). 
Caroline incident does not meet the generally accepted criteria for customary international law". ${ }^{6}$

As explained above, the right of self defence of a victim state against NSAS operating from other states is sought to be justified on several grounds. Two important grounds for justification, as discussed above, are based on the textual position of Article $5^{1}$ and the customary law nature of the right of self defence beyond the UN Charter. To give further clarification to the existing legal understating, clarificatory principles were also adopted in scholarly engagements. These are: the Chatham House Principles, ${ }^{17}$ the Leiden Policy Recommendations ${ }^{18}$ and the Bethlehem principles. ${ }^{19}$

In light of the arguments in favour of and against the right of self defence against non-state actors operating from the territory of another state even without latter's involvement, there has also been a focus on the state practice to justify respective contending views. One of the reasons for focusing on state practice is to establish whether that state practice led to an "agreement between the Parties" regarding the interpretation of Article 51 of the UN Charter. ${ }^{20}$ There is a possibility of a state practice being elicited from collective actions. It is equally important to know individual state actions for the purpose of understanding the formation of customary international law and/ or for the purpose of looking at the emergence of an agreement between the parties through subsequent practice. With that purpose, the next section will deal with India's state practice with respect to the use of force as self defence, particularly in situations in which it was involved in such use of force.

\section{India's State Practice}

In the backdrop of the above discussed legal doctrinal position, the following discussion evaluates India's state practice. India was involved in several armed conflicts of interstate nature since its independence in 1947. It was

\footnotetext{
$16 \quad I d$.

17 Wilmshurst, supra note 14.

18 Nico Schrijver \& Larissa van den Herik, Leiden Policy Recommendations on CounterTerrorism and International Law, 57 Nethe RLANDS Inte RnAtional LAW REvieW 531 (2010).

19 Daniel Bethlehem, Self-Defense Against an Imminent or Actual Armed Attack by Nonstate Actors, 106 American Journal of International LaW 770 (2012).

20 Vienna Convention on the Law of Treaties art. 31(3)(b), May 23, 1969, 1155 U.N.T.S. 331, 340 (entered into force Jan. 27, 1980) ("[A]ny subsequent practice in the application of the treaty which establishes the agreement of the parties regarding its interpretation").
} 
involved in wars since 1948-49 till now with its neighboring states, particularly Pakistan and China. ${ }^{21}$ However, for the purpose of the present chapter, the focus will be on recent military use of force, particularly after the September 11, 2001 incident. The reason behind choosing this timeline is based on the view that the question of the right of self defence against non-state actors gained prominence mainly after the September 11 incident. Though the discussion around the scope of Article $5^{1}$ and the right of self defence existed prior to the September 11 incident, post this incident, discussions shifted towards self defence against non-state actors operating from another state. It is also important that the UN Security Council adopted resolutions 1368 and 1373 after the September 11 incident. Often, there have been allegations and counter allegations between India and Pakistan on cross border terrorism. Sporadic incidents of military firing are reported, however, without leading to any warlike situation. There are also instances of the use of force with an intensity and reach which would amount to the use of force in the legal sense. There are two instances of such nature which took place in 2016 and 2019. These two incidents will be evaluated for the purpose of assessing India's state practice in relation to the right of self defence against non-state actors.

\subsection{Surgical Strikes of 2016}

On September 29, 2016, the Director General of Military Operations (DGMO) of India announced that the Indian army had conducted surgical strikes against terrorist launch pads across the Line of Control (LoC). LoC separates the Indian-and-Pakistani-administered Kashmir. ${ }^{22}$ The DGMO, in his briefing, contextualised the circumstances in which the surgical strikes were conducted. He informed that "there has been continuing and increasing infiltration by terrorists across the Line of Control in Jammu \& Kashmir". ${ }^{23}$ He further said that this infiltration "is reflected in the terrorist attacks at Poonch and Uri on 11 and 18th of September respectively. Almost 20 infiltration attempts have been foiled by the Indian army successfully during this year. During these terrorist attacks and infiltration attempts we have recovered items including Global Positioning Systems and stores which have had Pakistani markings". ${ }^{24}$

21 1948-49 India-Pakistan war, 1962 Sino-Indian War, 1965 India-Pakistan, 1971 IndiaPakistan War and 1999 India-Pakistan War. For a discussion, see Rudra Chaudhuri, War and Peace in Contemporary India, 42 Journal of Strate gic Studies 567 (2019).

22 In India, Indian administered Kashmir is known as Jammu and Kashmir. Pakistan administered Kashmir is known in Pakistan as Azad (free) Kashmir.

23 Transcript of Joint Briefing by MEA and MoD, Ministry of External Affairs, GovernMENT OF INDIA (Sept. 29, 2016), https://www.mea.gov.in/media-briefings .htm?dtl/27446/Transcript_of_Joint_Briefing_by_MEA_and_MoD_September_29_2016. 
The DGMO also informed that the matter was taken up with Pakistan in the past, and despite their urging "that Pakistan respect its commitment made in January 2004 not to allow its soil or territory under its control to be used for terrorism against India, there have been no letup in infiltrations or terrorist actions inside our territory". 25 Therefore, they went for this surgical strike. He further underlined that "[b]ased on very credible and specific information which we received yesterday that some terrorist teams had positioned themselves at launch pads along the Line of Control with an aim to carry out infiltration and terrorist strikes in Jammu \& Kashmir and in various other metros in our country, the Indian army conducted surgical strikes last night at these launch pads". ${ }^{26}$ The DGMO of India was clear that the strikes specifically targeted terrorists. He said that the "operations were basically focused to ensure that these terrorists do not succeed in their design of infiltration and carrying out destruction and endangering the lives of citizens of our country". ${ }^{27} \mathrm{He}$ further informed that "significant casualties have been caused to the terrorists and those who are trying to support them. The operations aimed at neutralizing the terrorists have since ceased". ${ }^{28}$

Some argued that India could justify its surgical strikes as self defence under international law. ${ }^{29}$ Another view justified surgical strikes on two counts. It was observed that:

[I]t was clearly an act of self-defence after the Uri attack; the Charter does not say the right of self-defence must be exercised within a prescribed time limit. Secondly, it was not legally speaking, an armed action in the territory of another state. After the partition of the Subcontinent, Pakistan signed a Standstill Agreement with the ruler of the state of Jammu and Kashmir. India did not sign this instrument. Pakistan launched an invasion of Kashmir despite having signed the Agreement. The ruler asked for India's help, but India refused in the absence of the ruler concluding the Instrument of Accession with India. Only after he did so did India rush troops to repulse the invaders. Thus, India's military action in 1947 and

$25 \quad I d$.

26 Id.

$27 \quad I d$.

28 Id.

29 See Yateesh Begoore, An Apologia for India's "Surgical Strikes" Against Terrorist Groups: The Conflict with Pakistan, Just SECURITY (Oct. 7, 2016), https://www.justsecurity.org/33409/ apologia-indias-surgical-strikes-pakistan/; George Thomas, The Right to Self-Defence, ТнЕ INDIAN EXPRESS (Oct. 24, 2016, 1:04 PM), https://indianexpress.com/article/opinion/ columns/surgical-strikes-kashmir-loc-indian-army-jihadist-terrorism-3099392/. 
all subsequent such actions, including the one on September 29, were within our own territory and hence not a violation of international law. ${ }^{30}$

Some other scholarly writings also favored categorizing Indian surgical strikes as justifiable under the right of self defence. They argued that "self defence" provides a solid international legal basis for Indian surgical strikes against terror launch pads, bases, or even states that provide 'aid' and 'assistance' to such terror groups to play havoc in India". ${ }^{31}$ There was an opinion favoring its justification under customary international law, rather than under Article $5^{1}$ of the UN Charter, as the right to use armed force pre-emptively for self-defense. ${ }^{32}$ Another view attempted to justify it under the "unable and unwilling" version of right of self defence. It argued that:

[U]nder the emerging customary status of the 'unable and unwilling' test, India has the right to use force in self-defence based on Pakistani inability or failure to prevent its territory from being a safe haven for terrorists. This is perhaps India's strongest argument not only to justify the strikes, but also to legitimately sanction further use of force against terrorists in Pakistan. ${ }^{33}$

There were also views which were skeptical of the justification of surgical strikes under self defence and under the unwilling or unable doctrine. ${ }^{34}$

While the scholarly and academic writings, mainly coming from India, attempted to justify the surgical strikes by India, they remained largely speculative or conjectural. The reason for this speculative or conjectural analysis can be attributed primarily to the imprecise legal position articulated by India. The

30 Chinmaya R. Gharekhan, An Act of Self-Defence, The Indian Express (Oct. 10, 2016, 1:12 PM), https://indianexpress.com/article/opinion/columns/surgical-strikes-india -pakistan-un-security-council-uri-attack-3074227/.

31 Bharat H. Desai, Surgical Strikes' by India: Taking International Law Seriously, $5^{2}$ ECONOMIC AND Political WeEkLY 23 (2017), https://www.epw.in/journal/2017/5/ commentary $/ \% \mathrm{E} 2 \% 80 \% 98$ surgical-strikes $\%$ E2 $\% 80 \% 99$-india.html.

32 Sanoj Rajan, Legality of India's Pre-emptive Surgical Strike in PoK, The WeEk (Oct. 10, 2016), https://www.theweek.in/content/archival/news/india/legality-of-india-pre -emptive-surgical-strike-in-pok.html.

33 Arpan Banerjee, Indian Surgical Strikes: Accelerating the Emergence of Nascent Norms of Use of Force Against Non-State Actors, Cambridge International Law Journal, (Sept. 6, 2017), http://cilj.co.uk/2017/og/o6/indian-surgical-strikes-accelerating-the -emergence-of-nascent-norms-of-use-of-force-against-non-state-actors/.

34 Srinivas Burra, How Does India's Decision to Conduct Surgical Strikes Hold Up in International Law?, The WIRE (Oct. 13, 2016), http://thewire.in/72642/does-indias-decision -to-conduct-surgical-strikes-hold-up-before-international-law/. 
Indian government's justifications do not seem to fit within the framework of the UN charter or international law. Additionally, India did not report the matter to the UNSC. While the DGMO's statement suggests that India had taken up the matter with Pakistan, it does not clearly attribute the terrorist activities to Pakistan. However, it does seem to indicate that there was unwillingness on the part of Pakistan to control the activities of the terrorist groups. What is clear from the DGMO's statement is that India does not wish to contextualise the strikes within the international law framework as it only emphasises on terrorist activities and their infiltration without giving any legal justification for the military use of force. Pakistan insisted that surgical strikes did not take place. Both countries seem to imply that it did not amount to use of force under international law as they seem to be aware of the implications of such assertions. The important implication here is that any use of force under international law effectively amounts to an armed conflict between two states in the legal sense. This imposes responsibility on India to justify its actions in accordance with the UN Charter and further legal and diplomatic assertions from Pakistan.

\subsection{Balakot Strikes of 2019}

On February 14, 2019, more than 40 Indian Central Reserve Police Force (CRPF) personnel were killed in a suicide bomb in Pulwama of Jammu and Kashmir in India. Pakistani-based Jaish-e-Mohammed (JeM) reportedly claimed responsibility. This led to an escalated military situation between India and Pakistan. As a response, India sent its Air Force (IAF) aircraft into Pakistan on February 26, 2019, and claimed that they targeted a JeM training camp near Balakot in Pakistan. The Foreign Secretary of India stated that "India struck the biggest training camp of JeM in Balakot",35 The statement stated:

The Government of India is firmly and resolutely committed to taking all necessary measures to fight the menace of terrorism. Hence this nonmilitary preemptive action was specifically targeted at the JeM camp. The selection of the target was also conditioned by our desire to avoid civilian casualties. The facility is located in thick forest on a hilltop far away from any civilian presence. ${ }^{36}$

\footnotetext{
35 Statement by Foreign Secretary on 26 February 2019 on the Strike on JeM Training Camp at Balakot, Ministry of External Affairs, Government of India (Feb. 26, 2019), https://www.mea.gov.in/Speeches-Statements.htm?dtl/31089/Statement_by_Foreign_ Secretary_on_26_February_2019_on_the_Strike_on_JeM_training_camp_at_Balakot. Id.
} 
The statement claimed that it was a non-military preemptive action targeted specifically at the JeM camp. Pakistan condemned ${ }^{37}$ the airstrikes and called it as "Indian violation of Pakistan's sovereignty and territorial integrity". Pakistan also referred to it as "Indian aggression". On February 27, Pakistan declared that their "Air Force undertook strikes across Line of Control from within Pakistani airspace". ${ }^{38}$ Pakistan further stated that their action was not retaliation to Indian belligerence and that its sole purpose was to demonstrate their "right, will and capability for self defence". ${ }^{39}$ They said, therefore, they struck at a non-military target, avoiding human loss and collateral damage. ${ }^{40}$ On the same day, India's Ministry of External Affairs (MEA) spokesperson, in a press briefing, confirmed that Pakistan has conducted airstrikes. He informed that India foiled Pakistan's attempts to target military installations and that one Pakistani fighter aircraft was shot down by the Indian Air Force. He further stated that India lost one MiG 21 and that a pilot was missing in action. ${ }^{41}$

Further, on the same day, it was informed in a press release by India that India condemned Pakistan's actions. The press release stated that " $t]$ he Acting High Commissioner of Pakistan was summoned ... by MEA to lodge a strong protest at the unprovoked act of aggression by Pakistan against India ..., including by violation of the Indian air space by Pakistan Air Force and targeting of Indian military posts". 42 The press release further stated, "[t]his is in contrast to the India's non-military anti-terror pre-emptive strike at a JeM terrorist camp in Balakot on 26 February 2019" and "Pakistan has acted with aggression against India". 43 These statements show that both sides were careful in legally categorizing their military actions. Both sides did not want to project their military actions as the use of force as a right of self defence. Thus, India stated that its use of force was non-military and that Pakistan wanted to show that it was

Pakistan Strongly Protests Indian Aggression, Violation of Its Airspace and Promises a Befitting Response, Ministry of Foreign Affairs, Government of Pakistan (Feb. 26, 2019), http://mofa.gov.pk/pakistan-strongly-protests-indian-aggression -violation-of-its-airspace-and-promises-a-befitting-response-2/.

38 Pakistan Strikes Back, Ministry of Foreign Affairs, Government of Pakistan (Feb. 27, 2019), http://mofa.gov.pk/pakistan-strikes-back-2/.

$39 \quad$ Id.

$40 \quad I d$

41 Statement by Official Spokesperson on 27 February 2019, Ministry of ExternAL AFFAIRs, GovernMENT OF INDIA (Feb. 27, 2019), https://www.mea.gov.in/media -briefings.htm?dtl/31098/Statement_by_Official_Spokesperson_on_27_February_2019. Pakistan Demarched on the Act of Aggression Against India, Ministry of ExternaL AfFairs, Government of India (Feb. 27, 2019), https:/www.mea.gov.in/press -releases.htm?dtl/3110o/Pakistan_demarched_on_the_act_of_aggression_against_India. Id. 
their "right, will and capability for self defence". ${ }^{4}$ However, both sides wanted to show that the other side's military action was an act of aggression.

Remarkably, India relied upon international humanitarian law in seeking the release of its pilot who went missing in action on February 27 and was captured by Pakistan. It stated:

India also strongly objected to Pakistan's vulgar display of an injured personnel of the Indian Air Force in violation of all norms of International Humanitarian Law and the Geneva Convention. It was made clear that Pakistan would be well advised to ensure that no harm comes to the Indian defence personnel in its custody. India also expects his immediate and safe return. ${ }^{45}$

India's reference here to the Geneva Convention seemed to point to the third Geneva Convention dealing with the protection of prisoners of war. The Geneva Conventions, including the third Convention, would apply in situations of international armed conflicts. India's insistence on the Geneva Conventions implied the existence of an armed conflict. For the purpose of the application of the Geneva Conventions, there is a need for the existence of an international armed conflict in the present context. It is important to note that initially there was a general caution in terming the situation as attracting the jus ad bellum framework. However, with the capture of the Indian pilot by Pakistan, India insisted that he should be treated in accordance with the Geneva Convention.

On February 28, Mr. Imran Khan, the Prime Minister of Pakistan, announced that the Indian pilot would be released. Accordingly, on March 1, the Indian pilot was released and handed over by the Pakistani authorities to Indian authorities at the India-Pakistan border. Pakistan stated that "Prime Minister of Pakistan Mr. Imran Khan announced his return as a goodwill gesture aimed at de-escalating rising tensions with India". 66 This statement says that the release of the pilot was aimed at de-escalating the rising tensions and was not a response to the deescalated situation. It further stated that the pilot was "treated with dignity and in line with international law". ${ }^{47}$ Reference to international law presumably indicates international humanitarian law

\footnotetext{
44 Ministry of Foreign Affairs, Government of Pakistan, supra note 38.

45 Ministry of External Affairs, Government of India, supra note 42.

46 Return of Indian POW, Wing Commander Abhinandan Varthaman, Ministry of Foreign Affairs, Government of Pakistan (Mar. 1, 2019), http://mofa.gov.pk/ return-of-indian-pow-wing-commander-abhinandan-varthaman/. 
and international human rights law. However, both states seemed to have preferred to maintain legal uncertainty.48

This military exchange is another instance to evaluate India's state practice on the issue of the use of force, particularly on the right of self defence. As a background to the use of force by India, the foreign secretary's statement underlined as follows: "Credible intelligence was received that JeM was attempting another suicide terror attack in various parts of the country, and the fidayeen jihadis were being trained for this purpose. In the face of imminent danger, a preemptive strike became absolutely necessary". ${ }^{49}$ The words "imminent danger" and "preemptive strike" would suggest the involvement of the right of self defence. However, the statement does not expressly mention the same. India could have invoked the right of self defence by attributing the actions of JeM to Pakistan. However, attribution was avoided by India. Instead, the Foreign Secretary informed that "non-military preemptive action was specifically targeted at the JeM camp". ${ }^{50}$ Reference to "non-military" must have been intended to convey that the attack only targeted the non-state actor on the territory of Pakistan and was not in violation of Pakistan's territorial sovereignty or political independence. However, this distinction does not serve much purpose as it does not help in creating any legal distinction between two positions. This was asserted by the International Law Association (ILA). The ILA observes in this regard that:

Accordingly, using force within the territory of another State - even if the forcible measures are limited to strikes against a non-state actor - must be considered as within the notion of force as it exists in Article 2(4) of the Charter. Distinguishing between forcible measures within but not against the State does not, therefore, provide a solution for the jus ad bellum concerns. As a consequence, the use of force in such circumstances will not be lawful unless justified by self-defence or Security Council authorisation. By accepting that self-defence may be invoked against a non-state actor located in another State, even absent attribution to this other State, the ensuing non-consensual force would not be a violation of Article 2(4) as it would be a lawful exercise of an exception to the prohibition. ${ }^{51}$

48 See Srinivas Burra, Legal Implications of the Recent India-Pakistan Military Standoff, Opinio JURIS (Mar. 19, 2008), http://opiniojuris.org/2019/o3/o8/legal-implications-of -the-recent-india-pakistan-military-standoff/.

49 Ministry of External Affairs, Government of India, supra note 35.

$50 \quad I d$.

51 Int'l Law Ass'n, Final Report on Aggression and the Use of Force, at 16 (2018) (footnote omitted). 
ILA favors the possibility of the right of self defence, without even attributing NSA actions to the host state. However, it is clear from India's positions that it did not want to call its military actions as self defence against the NSA activities. India could have claimed this position by attributing the actions of the JeM activities to the State of Pakistan. However, it did not mention it in any of its statements. It is also argued that there has been a growing view that even if a non-state actor's actions are not attributable to the host state, the victim state can exercise the right of self defence. It is argued that for this to happen, it should be established that the host state is "unwilling or unable" to deal with the activities of the non-state actor on its territory. ${ }^{52}$ India does not rely on the "unwilling or unable" proposition, despite the fact that it clearly emphasises the unwillingness of Pakistan in dealing with the activities of the JeM. India asserts that:

Information regarding the location of training camps in Pakistan and PoJK has been provided to Pakistan from time to time. Pakistan, however, denies their existence. The existence of such massive training facilities capable of training hundreds of jihadis could not have functioned without the knowledge of Pakistan authorities.

India has been repeatedly urging Pakistan to take action against the JeM to prevent jihadis from being trained and armed inside Pakistan. Pakistan has taken no concrete actions to dismantle the infrastructure of terrorism on its soil. ${ }^{53}$

These statements reveal India's view that Pakistan was unwilling to take action against JeM activities on its territory. Going by India's description of the situation, this would have attracted the "unwilling or unable" test. However, India did not rely on the "unwilling or unable" test to justify its attack as self defence. This unwillingness to use this test gains importance in the light of the fact that India was informed of its right of self defence after the Pulwama suicide bombing by the United States. On February 15, 2019, there was a telephonic conversation between India's National Security Advisor Ajit Doval and the United States' National Security Advisor Amb. John Bolton. A readout of the telephonic conversation said, "Ambassador Bolton supported India's right to self-defence against cross-border terrorism. He offered all assistance to India to bring the perpetrators and backers of the attack promptly to justice.

$52 \quad$ Id. at $14-15$.

53 Ministry of External Affairs, Government of India, supra note 35. 
NSA Doval appreciated U.S. support". ${ }^{4}$ Despite these suggestions, India did not go forward to claim it has a right of self defence to use force against NSA activities.

While looking at the state practice in relation to the "unwilling or unable" doctrine, a study identified India's position as falling under the ambiguous cases. The study said that ambiguous cases are those states "that have used force against non-state actors in third countries without clearly expressing their views on the legality of their actions under international law, and States that provided legal justifications but did not invoke the 'unwilling or unable' test or a similar concept in their justifications". ${ }^{55}$ While this criteria makes a fair proposition, it is equally important to take into consideration India's position in a multilateral context. India is part of the Non-Aligned Movement (NAM). The NAM continuously emphasises that "consistent with the practice of the UN and international law, as pronounced by the ICJ, the Article 51 of the UN Charter is restrictive and should not be re-written or re-interpreted". ${ }^{56}$ Clearly articulated multilateral positions and ambiguously presented explanations of its use of force so far reveal that India evidently refrains from supporting or using the "unwilling or unable" doctrine.

Arguments for the right of self defence against NSAs prominently come from a few states. These few states are mainly from North America and Europe. However, there are also a few states from the Global South that subscribe to this position. While it is important to know which states support or oppose this position, a methodological stance can be taken independent of states' positions. State practice helps us understand the existing international law. This happens mainly in the form of understanding customary international law as state practice constitutes an important component to elicit the formation of

54 Readout of Telephonic Conversation Between National Security Advisor Ajit Doval and US NSA AmbJohn Bolton, Ministry of External Affairs, Government of India (Feb. 16, 2019), https://www.mea.gov.in/press-releases.htm?dtl/31058/Readout_of_ Telephonic_Conversation_between_National_Security_Advisor_Ajit_Doval_and_US_ NSA_Amb_John_Bolton.

55 Elena Chachko \& Ashley Deeks, Which States Support the 'Unwilling and Unable' Test?, LAWFARE (Oct. 10, 2016, 1:55 PM) https://www.lawfareblog.com/which-states-support -unwilling-and-unable-test.

$5^{6}$ Non-Aligned Movement [NAM], 17th Summit of Heads of State and Government of the Non-Aligned Movement: Final Document, at 20, NAM 2016/CoB/DOC.1. Corr.1 (Sept. 17-18, 2016). 
customary international law along with opinio juris. Similarly, state practice is relied upon for the purpose of interpreting existing international treaty law. State practice is relied upon for the purpose of interpreting existing international treaty law as provided under Article $3 \mathrm{o}(3)$ (b) of the Vienna Convention on the Law of Treaties. ${ }^{57}$ The evaluation of state practice would also help to defend or critique a particular methodological position, like for the purpose of present article, providing a TWAIL critique. However, there need not be a necessary correlation between the third world state practice and the TWAIL approach in all circumstances. Coercive geopolitical considerations play a significant role in a particular practice of states often coming from the Global South. This can be the result of certain coercive measures by the dominant states from the Global North. Therefore, any evaluation of state practice should take these factors into consideration.

A TWAIL critique in general arguably, predominantly underlines the historical continuities in structurally oppressive international law. This structurally oppressive nature of international law's origin and its evolution took shape during the colonial period. Despite the decolonization and the subsequent changes in international law, its structural bias against the third world or Global South continues to shape the form and substance of contemporary international law. Extending this structural continuity argument to the current debates on international law on the use of force, it is argued that the structural bias of the past continues to occupy the substance of the present. In other words, the civilised and uncivilised distinctions of colonial times are reenacted in the arguments of the "unwilling or unable" doctrine debates. In this regard, Ntina Tzouvala argues that the "unwilling or unable" doctrine carries within it imperial aspirations and that they "form a 'red thread' that connect 'the standard of civilization' with the 'unwilling or unable' doctrine". ${ }^{58}$ However, this critique comes with a caution that at "an epistemological level, one should also keep in mind that there are limits to the explanatory potential of historical, genealogical accounts". ${ }^{59}$ Tzouvala further argues that the "unwilling or unable' doctrine replicates both the substance and the methodological preferences of nineteenth-century international law. The discourse of 'civilization' keeps returning in the discipline in a manner that questions its self-portrayal

57 According to Vienna Convention on the Law of Treaties art. 31(3)(b), state practice becomes relevant for the purpose of interpretation of an existing treaty. It reads as follow: "[A]ny subsequent practice in the application of the treaty which establishes the agreement of the parties regarding its interpretation [;]".

58 Ntina Tzouvala, TWAIL and the "Unwilling or Unable" Doctrine: Continuities and Ruptures, 109 American Journal of International LaW Unbound 266, 268 (2016).

Id. at 270. 
as a force of progress, freedom and peaceful co-existence".60 Tzouvala also, however, cautions that we need to keep in mind that contemporary international law is more than an "undercover" continuation of older international legal structure. "Striking the right balance between history and the present situation, continuity and rupture, constitutes the greatest challenge for TWAIL as a project that aspires to approach international law through emancipatory lenses". ${ }^{61}$ What comes out from this observation is the movement of international law from its oppressive past to the progressive or benign present. Thus, this movement bears ruptures which create certain discontinuities with certain progressive outcomes. This phenomenon is underlined in relation to the use of force with a justifiable argument that the law relating to the use of force is "perhaps one of the starkest examples of rupture in international law, and indeed of rupture generally, favorable to the interests and concerns of the states of the Global South".62

This apparently may be seen as presenting a challenge to the TWAIL methodology. This challenge may emerge from at least two conceptual follies. The first problem is that TWAIL's methodological framework is sought to be confined to critiquing historically ordained oppressive structures of international law in a linear fashion, from its origins to the present. This view tends to present the TWAIL methodology in a narrow and limited sense. Contrary to this, TWAIL not only has the potential to capture the "ruptures", but it also has the potential to generate methodological tools to critically analyze these changes in international law. Therefore, TWAIL's emphasis on international law's historical complicity in colonial oppression and its continuing role in perpetuating similar oppressions in the present cannot be seen as mechanical extension of TWAIL's methodological contours. Rather, it needs to be seen as underlining international law's historically embedded oppressive and instrumentalist role in different forms, while also recognizing the transformations that international law undergoes. Therefore, the TWAIL methodology has the potential to capture international law's movement not just in a linear way but with all its ruptures.

Secondly, to argue that the law on the prohibition of the use of force in itself is a virtue to be celebrated by the Global South would be to ignore the fact that it is the same law which gives the possibility of interpretation and application for the "unwilling or unable" doctrine. The same law which prohibits the use of force with exceptions arguably is sought to be applied or further exceptions are

$\begin{array}{ll}60 & I d . \\ 61 & I d . \\ 62 & I d .\end{array}$


articulated. But everything happens in reference to the existing law and not in total deference to it. Hence, it is necessary that what is argued as the product of a rupture from the past needs to be seen in continuities. However, pre-rupture and post-rupture international law cannot be equated as one and the same nor can they be rejected as oppressive in their totality. Such an equation or rejection leads to an argument of nihilism or nothingness which is difficult to sustain as a transformative and politically relevant alternative to the dominant mainstream. Therefore, it is necessary that any critique of the "unwilling or unable" doctrine needs to take note of the relevant United Nations Charter framework on the use of force in critiquing the doctrine. This may also involve defending the existing legal framework, despite the fact that it is the same law which gives rise to the formulations like the "unwilling or unable" doctrine.

However, this kind of dualism of comprehensive critique of the structures of international law in the historical sense and selective invocation of some aspects of international law for critiquing formulations like "unwilling or unable" doctrine can be seen as selectivity and opportunism. But this can be defended as the "principled opportunism" as conceptualised by Robert Knox in a similar situation. ${ }^{63}$ This principled opportunist position comes from the view that there are certain fundamental problems with international law from its past to the present. However, international law also provides contextual opportunities in a short term which can be invoked to sustain the internal critique of international law. Based on this proposition, the TWAIL argument may be built by seeking the need for confining to the textual position of Article $5^{1}$ of the UN Charter or invocation of chapter VII "Powers of the UN Security Council", rather than relying on the conceptually flawed "unwilling or unable" doctrine.

The law relating to the use of force as a right of self defence has been under strain in the last two decades, particularly after the September 11 incident. One of the controversial issues relating to the right of self defence is the argument for its permissibility against the NSAs operating from another state. This permissibility view relies on the existing treaty and customary international law. Opposite to it is the restrictive approach which rejects the permissibility view. The permissibility view also emphasises that there is an emerging state practice

63 Robert Knox, Strategyand Tactics, 21 Finnish Yearbook of International LAW 193, 222-27 (2010). 
in favour of the right of self defence against NSAs. Evaluating India's state practice reveals the fact that India so far has not subscribed to the permissibility view despite its involvement in situations of military use of force against NSAS in other states. It can be argued from this analysis that existing legal framework in the form of treaties and customary international law does not support the right of self defence against NSAs. A similar assertion is drawn from state practice, and the same is established through the analysis of India's state practice. A TWAIL critique while focusing on the historical continuities of structurally oppressive international law, also has the methodological potential to capture the ruptures which produce structural discontinuities in international law. UN Charter framework on the use of force can be seen as one of such structural ruptures which may be tactically defended against the problematic doctrinal deviations like the "unwilling or unable" test. 